\title{
Too much information. What to do?
}

Moraes-Filho JPP. Too much information. What to do? Arq Gastroenterol. 2018;55(Suppl 1):1.

It currently draws attention to the enormous amount of information available daily in the general media and on social networks, a phenomenon that has extended even to the medical area. In fact, it is peculiar the increase studies on prevalence, pathophysiology, diagnostic methods, therapeutic approaches and literature reviews that are available at the touch of the internet. Many of them have been carefully carried out following principles of evidence-based medicine and observing the principles of good clinical practice and can be said to be fully trusted.

Unfortunately, however, this is not always the case, because the information may not be reasonably correct and some publications may not be fully trusted. In fact, today's "scientific" journals are available, where there are papers of questionable quality regarding the methods of study, the therapeutic approach and the interpretation of the results. It has always been known that second- or thirdline articles are accepted in second or third line medical journals but, the difference today is the availability. With the ease media, such publications are disseminated as if they were credible and actually create a problem: when and who we trust? How to avoid falling into the universe of scientific works/reviews/low quality updates that provide supposed knowledge and can induce bad medical practice?

Answering these questions, in the first place let's remember the more important sites and reliable as Pubmed (National Institute of Health), British Society of Gastroenterology, American Gastroenterology Association, American College of Gastroenterology, The New England Journal of Medicine, The Lancet, among others. Studies and scientific projects of great importance have traditionally been published in known international journals related to the sites above. In addition to the scientific content itself, it should also be considered the critical view about what is being published in terms of diagnosis and therapeutic which are the doctor's tools in front of the patient.

In addition to the International field, it is worth mentioning that some Brazilian scientific publications are highly representative and trustworthy. This is the case, for example, of the role played by Archives of Gastroenterology (AG). Founded more than five decades ago, it has an interesting history of representation of medical societies related to gastroenterology and of publishing relevant works originating from national and international gastroenterological centers. The publication of good articles in AG constitutes an important differential and reflects the careful appreciation of the works that are submitted ("peer review").

This special edition of AG is a good demonstration of high quality articles that reflect the best in Latin American gastroenterology: thirteen outstanding, comprehensive and analytical works on the digestive tube. There are current themes that deserve attention from the specialist such as intestinal constipation, swallowing, diagnostic methods of gastroesophageal reflux, proton pump inhibitors, achalasia, anorectal function evaluation. The edition consists of four reviews/updates with critical analysis of the literature ${ }^{(1-4)}$ and nine original works of research/standardization of study methods ${ }^{(5-13)}$. Particularly draws attention the medical centers involved (Faculdade de Medicina de São Paulo - USP; Faculdade de Medicina de Ribeirão Preto - USP; Faculdade de Medicina de Botucatu - UNESP; Faculdade de Medicina da Universidade Federal do Ceará - UFC; Escola Paulista de Medicina - UNIFESP; Hospital Britânico de Buenos Aires - Argentina; Instituto de Ciências Biomédicas - UFRJ; Escola Bahiana de Medicina e Saúde Pública; Centro Médico de Diagnóstico Fleury - SP; MoDiNe - Instituto Brasileiro de Estudos e Pesquisas de Gastroenterologia e Outras. Especialidades-SP). Also highlighted are the authors who, in turn, stand out in their respective areas of expertise in the specialty.

We therefore have varied, current and reliable substrate to wish to the colleagues "Good Reading"!

Joaquim Prado P. de MORAES-FILHO*

Moraes-Filho JPP. Muita informação. Em quem confiar? Arq Gastroenterol. 2018;55(Supl 1):1.

\section{REFERENCES}

1. Maffei HVL, Morais MB. Proposals to approximate the pediatric Rome constipation criteria to everyday practice. Arq Gastroenterol. 2018·55(Suppl 1):56-60.

Costa MMB. Neural control of swallowing. Arq Gastroenterol. 2018;55(Suppl 1):61-75.

Costa MMB. Neural control of swallowing. Arq Gastroenterol. 2018;55(Supp 1):61-75.
Nasi A, Queiroz NSF, Michelsohn NH. Prolonged gastroesophageal reflux monitoring by impedance-pHmetry: a review of the subject pondered with our experience with 1,200 cases. Arq Gastroenterol. 2018;55(Suppl 1):76-84.

4. Azzam RS. Are the persistent symptoms to proton pump inhibitor therapy due to refractory gastroesophageal reflux disease or to other disorders? Arq Gastroenterol. 2018;55(Suppl 1):85-91.

5. Lasa JS, Altamirano MJ, Bracho LF, Paz S, Zubiaurre I. Efficacy and safety of intestinal secretagogues for chronic constipation: a systematic review and meta-analysis. Arq Gastroenterol. 2018;55(Suppl 1):2-12.

6. Del Grande LM, Herbella FAM, Katayama RC, Schlottmann F, Patti MG. The role of the transdiaphragmatic pressure gradient in the pathophysiology of gastroesophageal reflux disease. Arq Gastroenterol. 2018;55(Suppl 1):13-7.

7. Murad-Regadas SM, Regadas Filho FSP, Holanda EC, Veras LB, Vilarinho AS, Lopes MS. Can three-dimensional anorectal ultrasonography be included as a diagnostic tool for the assessment of anal fistula before and after surgical treatment? Arq Gastroenterol. 2018;55(Suppl 1):18-24.
8. Dantas RO, Cassiani RA, Santos CM, Alves LMT. Water ingestion dynamics in patients with achalasia: influence of sex and age. Arq Gastroenterol. 2018;55(Suppl 1):25-9.

9. Silva RMB, Herbella FAM, Gualberto D. Normative values for a new water-perfused high resolution manometry system. Arq Gastroenterol. 2018;55(Suppl 1):30-4.

10. Abreu GE, Dourado ER, Alves DN, Araujo MQ, Mendonça NSP, Barroso Junior U. Functional constipation and overactive bladder in women: a population-based study. Arq Gastroenterol. 2018;55(Suppl 1):35-40.

11. Viebig RG, Franco JTY, Araujo SV, Gualberto D. Water-perfused high-resolution anorectal manometry (HRAM-WP): the first Brazilian study. Arq Gastroenterol. 2018;55(Suppl 1):41-6.

12. Pinto RA, Corrêa Neto IJF, Nahas SC, Bustamante Lopes LA, Sobrado Junior $\mathrm{CW}$, Cecconello I. Functional and anatomical analysis of the anorectum of female scleroderma patients at a center for pelvic floor disorders. Arq Gastroenterol. 2018;55 (Suppl 1):47-51.

13. Souza TF, Grecco E, Quadros LG, Albuquerque YD, Azôr FO, Galvão Neto M. Short-term results of minimally invasive treatment of gastroesophageal reflux disease by radiofrequency (Stretta): first Brazilian series of cases. Arq Gastroenterol. 2018;55(Suppl 1):52-5. 